\title{
エドウィン・スミス・パピルスにおける語中改行
}

\section{The Split Spellings in the Edwin Smith Papyrus}

\section{塚 本 明 廣 TSUKAMOTo Akihiro}

ABSTRACT The words bridging the two lines in the Edwin Smith papyrus are not split arbitrarily. They do, however, follow several rules:

(1) More than one consecutive determinatives are never divided into two lines. The combinations are treated as inseparable single strings. And the determinatives, single or combined, have a tendancy to shift to the head of the next line.

(2) The grammatical morphs ( $x r$, jn, n) are never separated from pronominal suffixes. The combined string forms a indivisible unit. And they are placed at the head of the next line.

(3) The grammatical morphs (xr, jn) written alphabetically are never split, while lexical morphs spelled phonetically can be split freely.

These restrictions and other tendancies of spelling are tested and confirmed by other literary works in hieratic script with limited exceptions.

Considering these split words and words written within lines, and the fact that determinatives of lexemes vary freely, ancient Egyptian scribes must have already identified linguistic units. These correspond nearly to words, grammatical morphemes, and determinatives in contrast to phonogrames in modern linguists' terminology.

(1)

エドウィン・スミス・パピルス第 8 欄 6 行目から 7 行目（以下，用例の出現 欄と行を $8,6 / 7$ 等と略記) にかけて s3 といら単語が現れる。ガーディナーの コードに従らと $\{\mathrm{s} 3\}$ ! \{Z01\} と翻字されるこの単語は, 奇妙なことに, 縱線

* 佐賀大学教養部助教授

Associate Professor, College of Liberal Arts, Saga University 
$\{Z 01\}$ のみが次行行頭に先送りされている。この単語は，12,22（欄末）/13, 1 （次闌冒頭）にかけて統辞論的に全く同じ環境（Hr s3 n pSn pf）で現れ， そこでは語中で分断されることなく表記される。そのことを見ても，第 8 欄の この縦線の先送りは，理解し難い綴り方という印象を免れ難い。同欄の行末 $(8,22)$ に現机る Hsb の縦線の扱いを初め, 本パピルスで縦線が行末にかけ て現れる他の用例を総竣いすると，この印象は一層強められることになる。即 ち, 問題の s3 唯 1 例を除く23例に和いて, 語末の縦線は行内に収められてい るのである。

本文を一貫して横書きで通したスミス・パピルスの書記が，左行端を揃える ために縦線を行内に収めたり次行送りにしたりした訳ではなかったこと，換言 すれば，行末に多少の出入りが生じても書記の関知するところではなかったこ とは，パピルスの適当な 1 欄を眺めれば一目瞭然である。それどころか，欄頭 から欄末をで行頭を縦一直線に揃えた欄は，全22欄中表側が第6, 8, 10, 12, 13 欄 を，裏側が第18欄を指摘できる程度に過ぎず，パピルス全体からするとむしろ 少数である。第 $11 ， 19 ， 21$ 欄（の「呪文」の部分）に関しては，他の諸欄と比 ベると字数が少く行が短いが，各欄における行の長短と単語半ばでの改行の多 寡には直接的関係は見られない。また，エジプト文字に和いては審美的理由か ら文字の位置の転倒その他があることも知られているが，ここはその種の例に 当らず，かえって書記の審美眼を疑わせる表記である。

結局，8,6/7 で縱線を前行内に収められない積極的理由は見出せない。書記 は単語としての認識とは無関係に, 意味のまとまりを無視して，ただ機械的に 書き記しただけであろらか。単語という概念は近代の言語学者の発明であって, 古代人には無縁の抽象概念だったのであろらか。再び縦線 $\{Z 01\}$ の用例を眺 めると，それもをた極論に思われる。書記に単語としての認識があったからこ そ, 他の 23 例に执いては縦線を同一行内に収めたのであろら。何上りも, 単語 の切れ目と行の切れ目が一致する 352 例にも上る用例が, 明確な単語認識の存 在を証明してはいないだろらか。あた，限定符の様々な用法にも既に高度の言 語認識を有していたことが明かである。

では，問題の用例は例外的表記として簡単に片づけられる性質のものである らか。 $\{Z 01\}$ と翻字されるこの文字は, 実際はかなり太い縦線であり, 書き手 の意識に充分捕捉された筈である。したがって，単なる誤記とは片づけにくい。 
何よりも，誤記と認めることは，とりもな和さず原則の存在を前提することに なる。一体，改行に関わる分綴法なるものがあったのであるらか。そのことを 積極的に確かめるためには，語中で改行された用例全体を検討しなければなら ない。

同じく例外的と見なせる表記に，18,15/16の pr.f がある。この表記 [pr $]$ $\mathrm{r}\{\mathrm{D} 54\}$ ! $\mathrm{f}$ と行内收收める諸例之を比較せよ。人称接尾辞を行内纪書収める そのような表記は, 全部で103例, その中で pr.f 之同様に限定符と人称接尾辞 を持つ用例は55例㟧り，圧倒的な用例数から推して，[pr] r \{D 54\}！f の上 ら語尾の $\mathrm{f}$ の文次行に送るのが例外的であることは，ひとまず認められる。

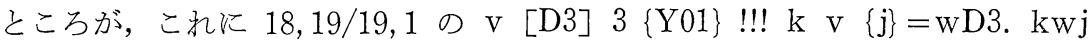
や 21,12/13 の x r ! t w =xr. tw を追加すると, これらを全く偶然の表記 そ断じることが躊躇される。なぜなら，この 3 例は人称語尾といら共通の文法 形式を伴う単語だからである。このような共通性は, 改行の際に古代エジプト の書記には全く意識されなかったのであらうか。用例数 3 例といらのは確かに 僅少である。意味上の共通点は偶然に過ぎないかししれない。しかし見方を変 兄ると，そのような共通特性を持つ用例が極端㐾少ないとも言光るのである。 換言すれば，このような用例数の偏りから推して，人称接尾辞の及を次行送り することは極力避けられたとは言光ないであるらか。このことの確認のために も，2 行に跨って表記された単語の詳細な検討が必要となる。

\section{I. エドウィン・スミス・パピルスにおける分緅法}

以上の上うな理由から, 行間を跨ぐ単語, 即ち単語半ばで行末に掛かり, 単 語の後半を次行行頭に送って表記せざるを得ない場合に古代エジプトの書記が 取った方策を一括して考察する。勿論, 語末と行末が一致するつまり行内に収 まる用例は 352 例㐫るのに対し, 語中改行の用例は, 復元箇所を除いて 109 例 (「外科症例」の部分 92 例，「呪文」の部分 7 例，「内科的処方」の部分 10 例） と， 数量的に愉前の方が遙か飞多いのであるから，単なる数值の比較は実態を眩 主す恐孔がある。以下の考察漈しては，西くまでも改行を余儀なくされた場 合が問題の焦点であることを忘れてはならない。でなければ，全てを偶然の仕 業として片ら゙けることもできるからである。逆に，単なる偶然に過大な読込反 をしないよらな用心も必要である。そのため, 孤例化基づく推論は極力避ける 
べきであろら。行内收市る形式を比較資料として参照するのは，そのような 一般化の行過ぎを避ける必要からである。要するに，用例数が偏る場合や余り にも異例と思わ秃る表記に対しては先机相応の理由が苏ったと考光た方が良い， といらのが本稿の立場で西る。8,6/7 に見ら机る改行も乥の一例ではないか， とするとそこで改行する理由があった筈だ，之筆者は考兄るのである。

説明の便宜上，ここでエジプト語の単語構造を概略的に示すと，語菓的形態 素十語幹形成形態素十人称接尾辞となり, 表記上は語彙的形態素の後に限定符 が入ることが多いけれぞも，語幹形成の文法的形態素の後に限定符が表記され (6) る場合も少数ながらある。以下の議論に打いては, 大多数は 3 子音からなる語 彚的形態素を $\mathrm{L}$, 限定符を $\mathrm{D}$, 語幹形成の文法的形態素を $\mathrm{M}$, 人称接尾辞を $\mathrm{P}$ そ略記する。したがって，公式風俍表記すると，LDMPとなる。DMPは随 意使用されるので，その何秃かをたは全部を欠くこともある。ちなるに，本パ ピルスの神官書体は添ぽ1文字ずつ書分けられていて連字が少ないのが特徵で ある。以下の諸例に和いても特に連字と関連づけた説明の必要性は感じなかっ (7) た。

語頭から順に検討していく。語頭からの字数を数觉てみると, 語頭から 2 字 目以降を次行に送るのが28例， 3 字目以降が31例，4字目以降が34例， 5 字・ 6 字目以降が16例となり, 最後の, 絶対数としても語数の少ないやや長めの単

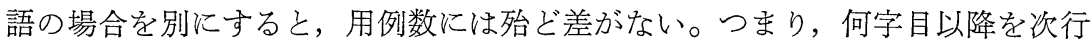
送りにするといった意味での用例の片寄り，言換光ると分経法は見られない。 念のため, 次行送りにされた文字数を基準に分類しても同様の結論に導かれ, 字数に基づく改行規則があったとは思克ない。音節の切れ目で改行された可能

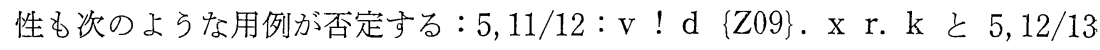
: v d $\{$ Z09\} ! x r k; 13,14/15:q 3 ! b t \{F51\}. f と 13,18/19: q 3 b ! t $\{\mathrm{F} 51\} . \mathrm{f}_{\mathrm{o}}$

とは言光, 再度資料を朓めると, 改行法に類するものは全然存在しなかった という印象が怪しくなる。と言らのは，語中改行により次行送りされた文字は， Lの部分を担う表音文字が大多数を占めるからである。Lの一部，末たは全部 が表記された後（つまりDの直前でもある）の改行は，全109例中，実に99例

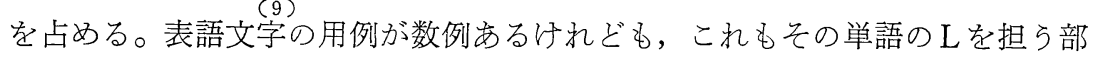
分であることに変わりはない。ところが，全 109 例の殆どを占める，Dを持つ 
形式94例についてみると，単語の意味を暗示するに留る部分つまり Dの表記直 後に改行した単語はのべ語数で僅か10例しかない。語末が Dで終る単語で行内 に収まる用例が 114 例も西るのに較べ，いかにも偏った数值である。しかも， その 10 例中 8 例が $M(x r ， j n ， n)$ を持ち，残る 2 例も $P(f, k w j)$ そ有する 形式である。上述の pr.f はその 2 例中に含まれる。逆に, 改行直後にDが現 れる例つまり D以下を次行行頭に書送る（Lの直後の改行とも言える）用例は 37 例, その中でMを持つ用例は僅か 2 例に留をる。このように, 用例に何らか の傾向性が観察される以上は，表記の偶然や書記の恣意だけで片づけることは でさないと思われる。そして，それに対する注意を喚起するのが，本稿の考察 のそもそもの発端であった。これまでの観察に基づくと, どらやら D以降に改 行の際の制約がありそらである。

上で検討したとおり，語中改行の用例でDを持つ単語全94例中，Dの直後で 改行するものが10例であるのに対し, 次行行頭にDが先送りされる用例は37例 である（残り 50 例近くはLの途中で改行されている）。Dは改行直前よりも改 行直後に現れる傾向がやや強いと言える。しかし，L D 型つまり MやPを欠く 単語の内, 行間を跨ぐ用例は52例（この中にはL内部で改行し, 必ずしも改行 直後にDが現れない用例も含む）であるのに対し，Dを当該行内に収めてしま ら用例はその倍以上の 122 例もあり, 用例数としては後者が遙かに多い。した

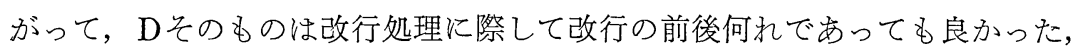
つまり制約はなかったように見光る。と共に，D以降を次行に送る分綴法は， 極く一般的に行われていたとも言光る。しかし，ここにMが関与してくると， 数值に幾らか偏りが現れる。DMといら連続が改行により分離される傾向が強 くなる現象である。るっとも，それを支持する用例は 7 例，否定する用例が 2 例となれば，拮抗しているとも言光る。これについては，下記を参照。

ところが，連続する 2 字以上のDを持つ単語の場合，行内に収まる60例近く の用例は無論のこと, 語中改行の 27 例を加えても, D D が改行前後に分けて書 か机た例は, 皆無である。つまり, 2 字以上の D D 一組の単位体として処理 された, と言える。さらに, 語中改行の用例中, DDが 2 字とも次行行頭に送 られたものは13例あるのに対し，2字とも前行に収めるのは僅か 1 例 (20, 18 : s j [jn] n \{Aa02\} \{D 36\} !!! x r k=sjn.xr.k) に過ぎない。残りはL内 で改行されている。しかもこの唯一の例外も, 見方を变光れば, 孤例どころか, 
DMは改行で分けるという，前節で見た別の一般的傾向に従った表記と見なし 得る。これにさらに, Dが 1 字の場合も加えると, D以降の次行送りは上述の と特り37例となり, 語中改行の場合に限ると, Dは次行に先送りする方が好ま れた，と言妄とである。すると，本稿冒頭に述べた 8,6/7の $\{\mathrm{s} 3\} ＼mathrm{~ ： Z Z 1 ~}$ もこの集団に属するとは考光られないだろらか。この綐線 $\{Z 01\}$ がDを意図 したものなら，行頭の縦線つまりDの次行行頭送りは何ら奇異な綴ではなく， かえって一般的傾向を反映した綴といらことになる。

$\mathrm{M}$ （xr，jn，n）を持つ形式は，語中改行の用例に18例，語中改行のない用 例飞13例, 合計31例が例証される。その内Dを持つ形式は, 語中改行の用例中 15例に上るけれども，DMといら二因子と改行との間に明確な関係を読取り難 いことは，前述した。ところが，Mを持つ用例は，2 例を除き，M P Pが付属 する形式である。そして語中改行の内， $\mathrm{xr}$ の 7 例，jn の 2 例， $\mathrm{n}$ の 1 例， 計 10 例でMが改行直後に現れ, 残りは L内での改行が 6 例, 前述の改行直後の $\mathrm{D}$ の出現が 2 例である。Mが改行直前に出現する例は, 両者合わせた 31 例中に 1 例しかない。乙かも，その場合の主語は代名詞ではなく名詞である $(3,7 / 8$ : [wn] n $\{\mathrm{O} 31\} \quad\{\mathrm{D} 36\} \quad \mathrm{x} \quad \mathrm{r} ＼mathrm{~ ！ ~}\{\mathrm{r} 3\} \quad\{\mathrm{Z} 01\} \quad \mathrm{f}=\mathrm{wn} . \mathrm{xr}$ r3.f「彼のロが開 く」。したがってMPが分断される用例は皆無, つまり, MPの結合形式を行 内に収められない場合は分割せずに一組として扱い次行に送るといら原則を認

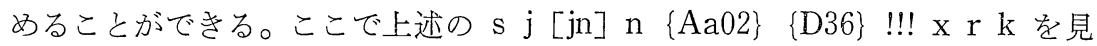
直すと，前項のDDを次行送りにする原則からは外れるが，この原則には適っ ている。換言すると，「MPは次行行頭に送る」といら原則が「DDは次行行 頭に送る」といら原則に優先したといらことである。MPを行内に収める12例 は，一見すると本節の原則を疑問視させる用例に見觉る。しかし， [mj]！ j, t $[\mathrm{tm}] ! \mathrm{m},[\mathrm{pr}] \mathrm{r}\{\mathrm{D} 51\}$ ! f 等の 17 例に明かなと敊り，1字のみ次行に送 ることもできた筈である。にも拘らず行内に収めたのは，MPといら結合にお いてはMとPの間で改行できない理由があったからではないだろらか。この結 合の P \&全て 1 字の形式で占められているので, 余白不足は改行の障害となら なかったことも理由の一つであららが，これについては後述も見よ。因みに， $\mathrm{tj}$ もここに入れるべきかも知れない。 $[\mathrm{Ss}] \mathrm{z} \mathrm{m}$ ! [ t j] j=Ssm.tj $(7,19 / 20)$ の用例から，tj がこのような Mの一つと意識されていた可能性があるからであ る。ただし，同じ形式を行内に収める例 $(7,23)$ も㐫上，tjの用例数が少な 
いのではっきりしたことは言えない。

結局，以上から明かなように，本パピルスに特いてMを有する形式が行末を たは行頭に掛かる場合，ほとんぞの用例でPを伴う（31例中29例）。この MP の結合自体は恐らく偶然の結果であろら。これに対し, 次の点は偶然の結果と は思觉ない。即ち, 単語全体を行内に収める12例の場合は当然のこととして, 語中改行の17例の場合にも，この二つの形態素MとPは一組の単位体として処 理されているのである。換言すると，MとP とが改行によって分断されること はなかった。さらに, xr, jn 等 2 字構成の $\mathrm{M}$ とのものが切断される例も皆無で ある。これは, 明らかに, 意味上の単位体つまり現代の用語を用い机ば形態素 として認識していたことの反映と思われる。そしてこれらは，音声言語の反映 とも言うべき性質のものであったかもしれない。

D P の組合わせは，語中改行をしない用例に51例，語中改行を行う用例に 26 例が例証される。後者の内，P以降を次行送りにするのは僅か 2 例に過ざず， 他は全て L内部 (13例) または L の直後即ちDの直前の改行 (11例) である。 つまりこれまで明らかになった原則に従ら用例ばかりである。Pは音声言語 として自立性が弱いため, それを反映した表記の上でも, MPの結合の場合と 同樣，DPの結合が分離表記されにくい。ただしD P の場合は，Dの性格上， MPの場合と違って音声言語の裏付けはなく, 綴字の約束事である。音声言語 で $\mathrm{P} か ゙ \mathrm{D}$ を越兄て直接 $\mathrm{L}$ 結合することは，上の数值にも現れている。この音 声上の支光の有無は，上述のDMに見られた不安定な改行原則をも説明する。 Dには音声上の裏付けがないため，DMを結合すべきか分離すべきか書記は迷 っているのである。そしてそのことが，原則としてょりも傾向性としてしか指 摘できない結果を生じていると思われる。

$\mathrm{P}$ に焦点を当てるとどらか。語末 $\mathrm{P}$ を行内に書収める用例が最少に見積もっ ても103例，語末にPを有する語中改行の41例と合わせた両者の合計が144例め る中で，MPやDPの結合形式とは逆に，Pのみを次行に先送りする用例は僅 か 3 例に過ざない $(18,15 / 16$ : pr ! f ; 18, 19/20：w D 3 !!! k w j; 21, 12/ $13: \mathrm{x} r \mathrm{t} \mathrm{t} \mathrm{w})$ 。このように, 压倒的多数の用例に和いてPを行内に書き収 めるのであるから，改行直後のP P出現は，例外的現象とすべきである。

3 人称単数男性形接尾辞 $\mathrm{f}$ の場合は, 1 字で表記できるので, 余白の大小は それ程問題でないと言えなくもないが，実際の字形は横長で，それ相応の余地 
を要求する大きさである。 L P ・ MP・D Pを一単位体とする認識が改行を妨 げたとでも考光ないことには，敢光て $\mathrm{f}$ を次行に先送りしない理由がか光って 理解し難いものとなる。語末の 1 字のみが次行に送られる用例に全部で17例岕 るけれども, その内 14 例は語末のDが関与しているので, むしろDの項で述べ たDの次行送りの原則の一証とすべき性質のものである。残る 3 例については, 確かにその原則では説明しにくいとは言え，上述の原則の反証とするには用例 数が相対的に少いため，より強力な原則を引出すことができない。これらが説 明できない限りは，例完ば，語末の 1 字がDでなければ行内收めるという原 則を引出すこともできない。

2 字で表記される tw の場合, 問題の用例 1 例を除く他の 32 例は全て $\mathrm{t} v$ と 表記され，その内の行末にかけて現れる唯一の例 $(7,13: \mathrm{jmj} . \mathrm{tw})$ も, 『医学 文書辞典』の解釈では $\mathrm{j} \mathrm{m} \mathrm{j.} \mathrm{t} \mathrm{w} \mathrm{m}-\mathrm{n} \mathrm{j}$ となって語中改行の例には違いな いが，例外と言う訳ではない。

3 字で表記される $\mathrm{kwj}$ の場合, 次欄に先送りする用例が本パピルスの唯一 の出現例であるため俄には断言できないけれども，3字分の余白が必要である ことから，行内に収めるには無理があったとも考光られる。たと書記が行末 を揃觉ることに無頓着であったとしても，極端な出入りは避けた筈である。上 述 pr.f の場合は，かなり横に長い f を書加兄ると行末に極端な凹凸を生じる ことになり，wD3.kwj の場合は，既に行全体が長く伸びきった状態にあった ことが，例外的表記を避けえなかった理由として考光られないだろらか。たと 光そのよな外的事情があったにしても，語末の 1 字を次行に送る [mj]！j 等の表記例と考台合わせる， $\mathrm{kwj}$ 内で改行しなかったことは，言語単位の 意識の現れといら観点からは重視すべさ事実と思われる。何れにしろ，例外の 2 例は第18欄の「呪文」の部分に例証されるので, 文書のジャンルによる綴字 法の違いを反映している可能性も考光られない訳ではない。と言うのは，他に も「症例」と「呪文」では経字法が異なっていたと思われる節があるからであ る。

例宎ば重字について言光ば,「症例」の [sSm] [sSm] v y (=sSm.wj : 5,$11 ; 5 ， 12 ; 5 ， 19 ）$ に対し，「呪文」には $\{\mathrm{swj}\} \mathrm{v} \mathrm{v}(=\mathrm{swj}: 18,13$; 18，19）といら表記が見られる。即ち，「症例」では [T32］の音価に関係な く重字自体が wj を表すのに対し（つまり vy は重複表記）「「呪文」では重 
字自体は wj ではなく， jを表す（だから wwj とならない）。その違いが， 同じく $w \mathrm{j}$ といら音形を持ちながら $\mathrm{v}$ の表記の違いとなって現れたと考光られ る。因みに，「処方」には二つの経字法が混在する。重字で $\mathrm{j}$ を表記する $\mathrm{zp}$ $\mathrm{p}[\mathrm{zp}]\{\mathrm{Y} 01\}$ (=spj : 21, 12) や [Sw $] \vee \vee\{\mathrm{N} 05\}$ (=Swj : 21, 11;21, $18 ； 22,1)$ と，Jの略記である [Sw] $\mathrm{v}\{\mathrm{N} 05\}$ (=Swj:21，10；21，18； 22,$1 ; 10,2$ 症例」にも) を比較。「処方」はをた 21 ，9以下で書体も代わっ ている。したがって，「処方」は別として，少くとも「症例」と「呪文」では 経字法が異なる原則に従っていることは認められるであるら。

\section{II. 作業仮説とその検証（例外の考察）}

以上の考察結果は, 次のようにまとめることができる。即ち, 経字法で改行 が避けられた位置を，制約が強い順に二ーで示すと： $\mathrm{L} \mathrm{D}=\mathrm{D}-\mathrm{M}=\mathrm{P}$ となる ら。つまり $\mathrm{D}=\mathrm{D}$ と $\mathrm{M}=\mathrm{P}$ の結合度が最も強く, $\mathrm{D}-\mathrm{M}$ の結合度は緩やかであ る。Mを欠く場合は, $\mathrm{L} \mathrm{D}=\mathrm{D}-\mathrm{P}$ の傾向が強い。 $\mathrm{M}=\mathrm{P}$ の結合の強さ, 換言 すればPの自立性の弱さは, 当時の文法理論から導かれた結論とするよりも， 言語現象として現れた結果（例えば，強勢の強弱や有無）を反映すると考光る のが，妥当なところであろら。DMとD P 結合では，D音声言語の支えの ないことが，改行処理に一貫性を欠く原因と思われる。一方， D=Dの結合の 強さは，限定符と表音文字との違いを意識していたことの反映と考兄られる。 そのことは，限定符が自由に交替する同一語の異表記から判断しても，充分有 り得たことである。

この作業仮説を，『難破した水夫の物語』（以下 S S と略記）・『生活に疲 れた者と魂との対話』（以下 B A）・『雄弁な農夫の物語』（以下 E P ）の三 文献に現れる語中改行の用例によって検証する。

\section{$1 \mathrm{~S} \mathrm{~S}$ の例外}

語中改行の用例23例中，仮定された分綴法を破る用例が 2 例ある。即ち，人 称接尾辞 $\mathrm{kwj}$ が途中で切れる用例が 1 例 (42/43, z [Dr] r \{A54\}. k ! w $\{\mathrm{j}\})$ ，改行直後の人称接尾辞の用例が 1 例 (70/71，w d f $\{\mathrm{G} 37\}$ (D54\}！k) である。 wdf.k の場合， DDを分割できないので余白の制約から 3 字分を一 括して次行送りにできなかったのであれば，その事情は理解できるが，Pを前 行内に収めきれなかった理由は分からない。kwj に関しては，BA 127/128亿 
も同様の例があるが，ここの例は説明がつかない。この形式を有する全18例中 ( 1 例は復元), 行末に現れて行内に書収められた用例が 4 例, 語中改行が 4 例あり，その中に上述の 1 例が含まれている。他の 3 例では $\mathrm{kwj}$ は分割表記 されない。残念ながら，神官畫体本文が入手できず，これ以上考察を進めるこ とができない。

\section{$2 \mathbf{B} \mathbf{A}$ の例外}

$17 / 18\{$ b3 $\} \quad\{Z 06\} ＼mathrm{~ ： ~} \mathrm{j}\}$ ：本稿の主張を否定する用例。直前の数行と長さを 比較しても，Pを次行送りしなければならない明確な理由は見当たらない。

$64 / 65\{[\mathrm{Hr}] \mathrm{r}[\mathrm{Hry}]-\{\mathrm{t} 3\} \quad\{\mathrm{N} 23\} \quad\{\mathrm{Z} 01\}\} ！\{\mathrm{~A} 01\}$ : 表語文字 $\{\mathrm{t} 3\}$ と $\mathrm{D}=\{\mathrm{N} 23\}$ の後に縦線 $=\{Z 01\}$ と $\{\mathrm{A} 01\}$ といらDが連続して現れると考え るなら例外となるが，複合語に対する $\mathrm{D}=\{\mathrm{A} 01\}$ のみが次行送りされている と解釈するなら，例外ではない。

69/70 S [mw] \{U09\} \{Z02\}！f:17/18 の b3.j と同じく, Pのみが次行 送りになっている。

127/128 $3 \mathrm{t} \mathrm{p}\{\mathrm{A} 09\} \quad\{\mathrm{D} 36\} . \mathrm{k}$ ! w $\{\mathrm{j}\}: \mathrm{P}$ である $\mathrm{kwj}$ のこのよらな切 り方は，SS42/43 にも見られる。wも $\mathrm{j}$ もかなり大きい文字であり，行内に収 めたとしたら，127行目だけがかなり間延びした印象を与えたと思われる。つ まり，それが例外を生じた理由と考えられるのであるが，kを $\mathrm{kj}$ と一緒に次 行送りにしなかったことの説明はできない。

128/129\{[cq] q $\{\mathrm{D} 54\}-\{\mathrm{jb}\}\{\mathrm{Z} 01\}\}$ ! $\{\mathrm{A} 01\}: 64 / 65$ のrj-t3 と同種。

BA は綎書さ文書で，行頭には出だしを揃えるための野線が引かれている。 行末には殆えど罢線がなく不揃いである。一部行末に野線らしきものが見える けれども，事実そらなのかどらかは写真では確認できない。野線内に収まる行 も実際は殆んどない。写真からはパピルスの繊維が野線の役目を果たした可能 性も椝われる。全 155 行の本文中に，語中改行は29例ある。Pを持つ形式が10 例見られる中で，明らかな例外として指摘できる用例は 3 例，その内 2 例は改 行直後に $\mathrm{P}$ 表記する例， 1 例はPの $\mathrm{kwj}$ を分断する表記である。3 例とも 改行（直）前にD方ある。S S 場合も，例外形はこの二つの型に限られた。 つまり，S SとBAは同じ分綴法に従ら文献であるとも考允られる。

\section{$3 \mathbf{E} \mathbf{P}$ （文献 B 1）の例外}

38/39 [w3] 3 t \{N31\} t ！n \{Z02\}：「わたしたちの道」といら訳は，改行 
直前の $\mathrm{t}$ を $\mathrm{w} 3 . \mathrm{t}$ の語尾表記と解釈したものである。並行箇所 R9, $2:\{\mathrm{w} 3 . \mathrm{t}\}$ $\mathrm{t}\{\mathrm{Z} 01\}$ や $1,40:\{\mathrm{w} 3 . \mathrm{t}\} \mathrm{t}\{\mathrm{Z} 01\}$ を参照。この場合, 複数 1 人称語尾 $\mathrm{n} の$ 及を次行送りにしたことになる。複数 2 人称語尾 tn「あんたらの道」とする のは，「天下の公道」を主張する前後関係から不適である。この く書かれているので， $\mathrm{r}$ とも解し得る。その場合は，r.n「わしらに（道を塞い でいる)」といらことになろらか。何れにしろ，これがPに関する例外である ことに変りはない。ところで，同じ39行行末に sw3.n「わしらが通る」という 動詞があり，その 1 人称複数語尾nは次行行頭に送らず，次行行末に食い达む 形で, s [w3] 3 \{Z09\} \{N31\}.n \{Z02\} と書かれ，改行を避忷た様子が伺光 る。となると，Pに関する仮説を支光る一証と言光るが，同一行内に現れた同 一形態素に対する扱いが違ら理由ほわからない。指摘できるのは語幹の品詞の 違いだけである。

131/132 s r f v \{D19\}！\{A02\}：\{D19\}はかなり横に長く，この段階で 既に他の行，特に直前の行末に比べて飛出た状態にある。そのことが改行を余 儀なくされた事情であったのかもしれない。また，写真によれば，この字の直 後に他と異なる円形に近い欠撌が見られる。もしこれが既に書写の時点で存在 したとしたら，改行は避けられないものであった。

222/223 s [sSm］ｍｖ＼{D54\} \{A01\}！s：この縦書き部分の行は, 既に全 } 体が長く伸びていて，行末の $\{\mathrm{A} 01\}$ は，行末揃えのためか，極度に压縮した 字形を用いている。この上さらに，縦長の文字である $\mathrm{s}$ を書加光ると，行末が 突出し，恐らく美観を損らことになったと思われる。\{A01\} 同様にs の字を圧 縮して行末に続けることは，文字の識別上問題があったのではないだろらか。 例光ば338行末の $\mathrm{S}$ を参照。 $\{\mathrm{A} 01\}$ に並べて書くとら手もあったと思われるが， 書記は既に $\{\mathrm{A} 01\}$ を行幅一杯に書詰めていた。これも，\{D54\} \{A01\} とい らDの連続を分割しないといら規範を意識した結果ではなかららか。

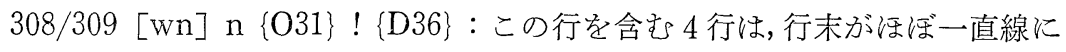
揃っているので，横長の文字である $\{$ D36 $\}$ を行内に收めようとすると，突出 てしまら。行末はかなり意識的に揃光られた形跡がある。しかし，同欄 6 行目 （310）では行末が極端に飛出ることも敢えて避けてはいないことから，行末 揃光にどの程度の拘束力があったのか疑問である。ところで, その 6 行目不揃 いの原因となった S $3 \mathrm{mw} . \mathrm{j}$ は 3 字続きの D 
の主張を支持する用例である。

339/340 q r s. t \{T19\}！\{A24\}. f.：行末を特に揄光たためとも思光ない，

DDを分割する強力な例外。

以上， 2 字以上連続するDが分割表記された例外が 3 例，Pのみが次行に送 られた例外が 2 例, 計 5 例の例外が見られる。したがって, 全行数 357 行から なる B1 の本文中に，語中改行の用例が49例，例外はその内 5 例之なる。換言 すると，残り44例に関しては例外ではなく，その中で本稿の主張を積極的に支 持する用例は，限定符の連続に関しては11例める。正確に算定するには，さら に行内に書収めた用例も含めた検討が必要かもしれない。文献 $\mathrm{B} 2, \mathrm{Bt}, \mathrm{R}$ に 関しては，欠損行が多いため単純に比較できないものの，行数はそれぞれ 147 行, 42 行, 194 行ある中で, 全て単語境界と行末が一致し, 語中改行の用例は 皆無である。当然, 例外がない。このことから, B2, Bt, R に执いても, 単語 が言語単位として明確に認識されていたことは明瞭である。書記は単語として の一体性を強く意識したからこそ，他の文書にはごく一般的にみられる語中改 行さ光，避けたとしか考岳られない。B1 の例外は，5例に過ぎないとも言え るし，用例数としてやや多いとも言觉る。たと兄多いとするにしろ，上で検討 したと括り，個々の事例に特いて例外的表記を余儀なくされた事情もある程度 理解されるのである。そして, 以上の考察が妥当であるとすると, 本稿の仮説 と真っ向から対立する重大な例外は極めて僅かとなり，誤記の範囲に収めるこ ともできるであろら。

\section{結ひび}

エジプト語文書は，日本語と同様，分ち書きをしない。しかし，審美的理由 による禁則処理を施す以外は字数によって機械的に改行する現代日本語の表記 と暴なり，改行には何らかの制約があった。ある文書は単語を分断するよらな 改行を認めず，ある文書は特定の形態素や文字連続の分断に制約を加え，他の 文書は別の方針をとった。その点で，むしろ，句読点を欠いた過去の日本語の 表記を思わせるものがある。文書毎に違いが見られるとは言光，それぞれの文 書内では方針は一貫しているよらに見える。そのことに注意を喚起することが できれば，本稿に拈ける所期の目的は，ほぼ達成されたと言ってよい。

さらに敷衍すれば，語中改行の諸例にも，古代エジプト人の言語認識の一端 
が窺われるとは言光ないであろらか。即ち古代エジプトの書記は，単語の認識 は言らまでもなく，形態素に対応する文法上の単位体も幾分は認識していた。 そのことは，例光ば，単語の語彙的意味を担う部分と文法的意味を担う部分で ある語幹形成形態素や人称接尾辞等の改行の際の扱いの違いに窺われる。また， 彼らは限定符が表音文字と異なる範躊であることを, 明確に意識していた。そ のことは, 同一語の異表記だけでなく, 改行の際の文字の処理にも明瞭に簯觉 る。限定符と表音文字との区別は近代の分析的な知性を有するエジプト学者の 考案に過ぎず古代エジプトの書記にそのような現代言語学の概念があった筈が ないとは断言できまい。このよらな認識が，抽象的文法理論に基づかなくと も具体的な言語使用の過程から充分生まれ得たことは，考兄られることである。 まさに，『文字の創始者はある意味では言語学者であった。それは，文字を始 めて創り出した人は必ずその言語を反省したにらがいないからである。…… まり，文字で表語することによって「語」が出来た』のである。

\section{注}

(1) J.H. Breasted, The Edwin Smith Surgical Papyrus, 2 vols., Chicago, 1929.

(2) Sir A.Gardiner, Egyptian Grammar ${ }^{3}$, Oxford, 1957, p.438 以下。ここで用 いた翻字法は，機械処理を考慮した以下の文献を参考にし，さらにパソコンでも処理 可能なように手を加光, 表音文字と表語文字・限定符は［］と＼{＼}で区別し，改 行と改欄は!と!!! で表記した。J. Buurman et al., Inventaire des signes hiéroglyphiques en vue de leur saisie informatique, Paris, 1988 は, 文字の微細 な相違だけでなく，文字の位置関係さ光も反映できる聖刻書体用のコード体系である が，それらは本稿の目的にとって過剩な情報と判断し，入力の便宜も考慮して，より 簡略化した翻字法を用いた。W.Schenkel, Aus der Arbeit an einer Konkordanz $z u$ den altägyptischen Sargtexten, Teil I: Zur Transkription des HieroglyphischÄgyptischen (unter Mitarbeit von R. Hanning), Göttinger Orient forschungen IV, 12, Wiesbaden, 1983 は, 上とはまた異なるコード体系で改変記号の多用と活字 ポイントの使い分けがあるため, パソコン次第では利用しにくい翻字法である。

(3) 出現筒所は以下のと拈り $: 1,24 ; 5,9 ; 5,20 ; 7,5 ; 7,18 ; 7,22 ; 8,22 ; 10,3 ; 11$, $14 ; 11,15 ; 12,1 ; 12,14 ; 13,15 ; 13,17 ; 15,10 ; 16,12 ; 17,2 ; 18,9 ; 19,8 ; 20,6$; 21,$5 ; 21,15 ; 21,21$ 。用例は wc(.t)「一つの」が 5 例，Hr「の上」が 4 例等である が，それぞれののべ語数が順に19例と約 100 例であることを考觉ると，wc(.t) の場合， 頻度の割には行末の用例が多いといら印象が残る。

（4）例えば，複合語全体に掛かる限定符に関してガーディナー，上揭書，p.52を見よ。 
また，限定符が単語境界を表示する機能を持つことについては，A.H.Gardiner，The Theory of Speech and Language ${ }^{2}$, Oxford, 1951, p.122 を参照。

( 5 ) 1,$1 ; 1,6 ; 1,15 ; 1,17 ; 1,23 ; 2,2 ; 2,7 ; 2,11 ; 2,19 ; 2,22 ; 3,2 ; 3,4 ; 3,8 ; 3$, $9 ; 3,13$ 等。語中改行の全用例と，語末が行末と重なる全用例は，紙幅の都合で列挙 できない。

（6）ガーディナー，上揭書， p. 235 。 $3,3 / 4$ に，人称代名詞の後に限定符を持う $\mathrm{j}$ ! S. f $\{\mathrm{A} 02\}$ の例さ光あるが，本文書では極めて異例である。しかし，W. Westendorf， Grammatik der medizinischen Texte, (Grundriß der Medizin der Alten Ägypter VIII), Berlin, 1962, S.8 によれば，医学文書には散見されるようである。

(7) M.Megally, Considérations sur les variations et la transformations des formes hiératiques du Papyrus E.3226 du Louvre, Bibliothéque d'étude 49, Le Caire, 1972, p.37 は，連字の発生要因を幾つか揭げている。本稿との関連では， 語中や語末よりも語頭の方が略記が起こりにくいとか，Dの連続が連字を生じ易いと いら指摘は興味深い。けれども，連字が少ないスミス・パピルスの状況から判断する と，連字の存在が改行の原則に影響を与えたと言うょりも，改行の原則を支配したと 同じ，言語単位に対する書記の意識が，連字発生の真因であったと筆者は考学る。ム ガリの指摘で最も興味深いのは，頻度即ち彼の言う言語上の要因が連字発生に影響し たといらものであるが，これも，上述の理由から，本パピルスでは直接の影響を云々 することはできない。

（8）語頭より数光て, 2 字目以降 : $2,23 / 24 ; 3,3 / 4 ; 3,19 / 20 ; 4,15 / 16 ; 5,11 / 12$ 等 ； 3 字目以降 : $2,24 / 25 ； 6,15 / 16 ； 7,14 / 15 ； 9,20 / 21 ； 10,4 / 5$ 等； 4 字目以降 : 4, 5/ $6 ; 4,12 / 13 ; 5,12 / 13 ; 5,21 / 22 ; 6,4 / 5$ 等； 5 字目以降 : $3,12 / 13 ; 4,10 / 11 ; 6,1 / 2$; $8,10 / 11 ; 14,20 / 21$ 等 : 語末より数光て 1 字のみ: $5,21 / 22 ; 6,1 / 2 ; 13,12 / 13$ 等 17 例 ; 語末 2 字: $6,13 / 14 ; 7,7 / 8 ; 8,10 / 11$ 等 29 例；語末 3 字 : $2,4 / 5 ; 4,5 / 6 ; 4,10 / 11$ 等 27 例；語末 4 字: $6,4 / 5 ; 6,11 / 12 ; 7,21 / 22$ 等 24 例。語末 5 字以降 12 例。

（9）表語文字を含む文字論の用語と理論については，河野六郎「文字の本質」『河野 六郎著作集 3 』平凡社, 1977年, 107 頁以下を参照。エジプト文字の場合, 表語文字 自体ではなく，振り仮名・送り仮名相当部が分割される。共時論的には，振り仮名付 きの表語文字と限定符を伴う表音表記との俊別はできない。本稿では，問題の 1 字を 省いても音形が確定できる場合，それを限定符とした。

(10) $5,12 / 13 ; 5,17 / 18 ; 6,16 / 17 ; 12,4 / 5 ; 12,12 / 13 ; 17,18 / 19 ; 18,15 / 16 ; 18,19 /$ $20 ; 20,18 / 21,1 ; 21,18 / 19$ 。

(11) $1,26 / 2,1 ; 2,3 / 4 ; 2,17 / 18 ; 2,18 / 19 ; 2,24 / 25 ; 3,12 / 13 ; 4,14 / 15 ; 5,14 / 15 ; 5$, $21 / 22 ; 6,1 / 2 ; 6,6 / 7 ; 7,7 / 8 ; 7,11 / 12 ; 7,20 / 21 ; 8,6 / 7 ; 8,8 / 9 ; 8,10 / 11 ; 10,6 / 7$; $11,10 / 11 ; 11,22 / 23 ; 12,5 / 6 ; 13,6 / 7 ; 13,12 / 13 ; 13,22 / 14,1 ; 14,9 / 10 ; 14,11 / 12$; $14,20 / 21 ; 15,6 / 7 ; 15,12 / 13 ; 15,14 / 15 ; 15,18 / 19 ; 16,6 / 7 ; 16,19 / 20 ; 18,13 / 14$; 19,20/20,1；20,14/15；21,6/7。この内，Mを持つ形式は11,10/11と13,6/7だけであ 
る。

(12) $5,12 / 13 ; 5,17 / 18 ; 6,16 / 17 ; 12,4 / 5 ; 12,12 / 13 ; 17,18 / 19 ; 21,18 / 19$ は と $\mathrm{M}$ の間で改行。DM が連続するのは $5,11 / 12 ； 6,11 / 12 ; 9,19 / 20 ; 11,10 / 11 ; 13,6 / 7$; 13, 20/21；21, 11/12の 7 例あるが，内 5 例はLの部分での改行である。ここでは DM !P（用例なし）または! DM (11.10/11；13,6/7）が該当用例。行内に収まる用例 中，語中にDMの連続を持つものは13例ある。

(13) $1,26 / 2,1 ; 2,17 / 18 ; 2,24 / 25 ; 3,10 / 11 ; 3,15 / 16 ; 5,14 / 15 ; 6,7 / 8 ; 12,5 / 6 ; 12$, $17 / 18 ; 13,22 / 14,1 ; 14,5 / 6 ; 14,20 / 21 ; 14,22 / 23 ; 14,23 / 15,1 ; 15,6 / 7 ; 15,11 / 12$ ; $15,18 / 19 ; 18,13 / 14 ; 19,20 / 20,1 ; 20,8 / 9 ; 20,14 / 15 ; 20,18 / 21,1 ; 21,6 / 7 ; 21,9$ $/ 10 ; 21,11 / 12 ; 22,6 / 7 ; 22,8 / 9$ 。

（14）語中改行 : $2,4 / 5 ; 4,5 / 6 ; 5,11 / 12 ; 5,12 / 13 ; 5,17 / 18 ; 6,11 / 12 ; 6,16 / 17 ; 9$, $19 / 20 ; 10,10 / 11 ; 11,10 / 11 ; 12,4 / 5 ; 12,12 / 13 ; 13,6 / 7 ; 13,20 / 21 ; 17,18 / 19 ; 20$, 18/21, $1 ; 21,11 / 12 ; 21,18 / 19$ 。行内 : 3,$4 ; 3,7 ; 3,9 ; 3,13 ; 6,9 ; 7,9 ; 8,12 ; 10$, $16 ; 11,5 ; 11,19 ; 12,13 ; 14,19 ; 21,1$ 。

(15) $15,17 / 18 ; 16,15 / 16 ; 18,15 / 16$ と(18)の言及箇所。

(16) $21,11 / 12:[\mathrm{x} 3] 3$ ! [x3] 3 \{P05\} \{D54\}x r t v=x3x3.xr.tw は L 部分での 改行。

（17） Pのみ次行送り：18,15/16；18,19/20。 L内での改行 : 3,3/4;3,10/11;3,18/ $19 ; 6,4 / 5 ; 7,21 / 22 ; 9,20 / 21 ; 10,4 / 5 ; 11,7 / 8 ; 13,14 / 15 ; 13,18 / 19 ; 15,7 / 8 ; 16$, $2 / 3 ; 17,13 / 14$ 。改行直後の D : $2,24 / 25 ; 3,12 / 13 ; 4,14 / 15 ; 5,14 / 15 ; 7,7 / 8 ; 8,10$ $/ 11 ; 10,6 / 7 ; 11,22 / 23 ; 12,5 / 6 ; 15,14 / 15 ; 16,19 / 20$ 。

(18) $2,3 / 4 ; 2,18 / 19 ; 5,21 / 22 ; 6,1 / 2 ; 6,6 / 7 ; 7,11 / 12 ; 7,20 / 21 ; 8,6 / 7 ; 8,8 / 9$; $13,12 / 13 ; 14,9 / 10 ; 14,11 / 12 ; 15,12 / 13 ; 16,6 / 7$ 。

(19) H. von Deines und W.Westendorf, Wörterbuch der medizinischen Texte, 2 Bde (Grundriß der Medizin der Alten Ägypter, VII 1-2), Berlin, 1961.

（20）例光ば， wbnw では $\{\mathrm{D} 26\}$ と $\{\mathrm{F} 51\}$ が (2,3と3.2；3,9亡3.9他多数), cH3 では $\{\mathrm{A} 24\}$ と $\{\mathrm{D} 36\}$ と $\{\mathrm{D} 40\}$ が $(2,11 ; 3,6 ; 8,9$ 等全 9 例 $)$ 自由に交代し, Sbb では $\{F 51\}$ に $\{\mathrm{F} 10\}$ を加光る $(9,22$ と 9,19$)$ 等，用例は数多い。

（21）ここでも，紙幅の制約で，直接関連する箇所しか揭げられない。本文は以下を参 照した。A. M. Blackman, Middle-Egyptian Stories, (Bibliotheca Aegyptiaca II), Bruxelles, 1972; W. Barta, Das Gespräch eines Mannes mit seinem BA, Münchner Ägyptologische Studien 18, Berlin, 1969; R. B. Parkinson, The Tale of The Eloquent Peasant, Oxford, 1991; F.Vogelsang und A.H.Gardiner, Die Klagen des Bauern, (Hieratische Papyrus aus den Königlichen Museen zu Berlin IV), Leipzig，1908。詳細な文献紹介と邦訳が屋形禎亮『筑摩世界文学大系 1 古代オリエ ント集』筑摩書房，1978年，401頁以下にある。

（22）ガーディナー，上揭『エジプト語文法』 p.235 には，kwj のwや wj を省略し 
た形が『シヌへ物語』とS Sから挙げられている。何れも行半ばに現れる。ここの用 例と共に，既儿音形上の支觉を失っていた可能性が考光られる。J. Černy \& S. I. Groll, A Late Egyptian Grammar, Rome, 1975, p. 195, 2. a. も参照。

（23）ガーディナー，上掲書， p. 53 も同解釈。改行規則を破る用例が経字もまた変則 的であることは単なる偶然であるらか。

（24）スミス・パピルスにも語末が行末と重なる用例が約 350 例あったことは既に述べ た。

（25）河野, 上掲書, 125 頁。単語認識に高度の言語理論は不要, とする E. Sapir, Language, London, 1921, p.34 も参照のこと。ガーディナー（上揭『理論』，同頁） もこれに従うが, 限定符と文法語尾の位置は, スミス・パピルスでは彼が指摘する程 不安定ではない。サピアは, 音韻特徴が単語認定に影響を与兄るのではなく, 単語の 心理的実在が音韻面に顕現するのだと言う(上掲書, p. 35)。何れにしろ, 単語認識に 直接影響する文字使用といら観点はない。ライオンズ (J. Lyons, Introduction to Theoretical Linguistics, 1968, 特に p. 199）も，文字表記が単語認知力を高めること はないと言う。けれども，表記しなければ単語という単位体も意識され妨まずあっ たに違いない。また，単語がそれ程明確に認識されるものなら，そのような単位体を 分断する語中改行には，かなりの抵抗があったと思われる。分ち書きをする言語にお いては，単語の認識は表記に如実に現れる。だからこそ，書き手の直感の首尾のなさ， と言うより言語自体の性質（河野，同書，同頁）を反映して表記に一貫性がない。分 ち書きをしないエジプト文字においては，単語認識を明示する手段も，したがってそ の有無を判断する材料も限られる。現代のエジプト学者と同様, 古代エジプトの畫記 にとっても事情は異ならなかったであるら。そのよらな状沉の下で，彼らに単語とい ら単位体を鮮明に意識させる役割を果たしたのが, 文字, とりわけ限定符だったと言 えるのではないだろらか。

(1993. 10.15) 